\title{
THERMODYNAMIG PROPERTIES OF INDANE AND INDENE
}

\author{
D. R. Stull, G. G. Sinke, R. A. MaDonald, W. E. Hatton and \\ D. L. HiLdendBRAND
}

Thermal Laboratory, The Dow Chemical Company, Midland, Michigan, U.S.A.

\section{INTRODUCTION}

Over a score of years ago, Dolliver, Gresham, Kistiakowsky and Vaughan ${ }^{1}$ measured the heat of catalysed hydrogenation at $100^{\circ} \mathrm{C}$ of indane and indene to the same hydrogenated product, which was presumed to be a mixture of isomers whose identity and concentration were not definitely established. The difference between these measured heat values is a measure of the heat of hydrogenation of indene to indane. More recently Naidus and Mueller ${ }^{2}$ measured the equilibrium constants by a flow method for the system indane-indene-hydrogen from $375^{\circ}$ to $535^{\circ} \mathrm{C}$. From these equilibrium data these authors calculated the heat, entropy, and free energy changes for the hydrogenation reaction over the temperature range studied. Since the industrial importance of these materials has increased in the past few years, the following measurements were undertaken to extend our knowledge in this area. The heat capacities of indane and indene were measured from $15^{\circ}$ to $320^{\circ} \mathrm{K}$, and their heats of combustion were determined by standard bomb calorimetry.

\section{EXPERIMENTAL}

\section{Materials}

Indane-Commercial material was purchased from the Aldrich Chemical Company, Milwaukee, Wisconsin, and was further purified by distillation. The equilibrium melting studies indicated the indane to be 99.89 mole per cent pure. The calorimetric sample weighed $62 \cdot 245 \mathrm{~g}$ corrected to a vacuum basis and the molecular weight was taken as $118 \cdot 179$.

Indene-Commercial material was purchased from the Chemical Research and Intermediates Laboratories, Akron, Ohio, and was further purified by distillation. The equilibrium melting studies indicate purity in the range 99.7 to 99.9 mole per cent, although this has not been clearly established because of solid solution phenomena. The calorimetric sample weighed $63.900 \mathrm{~g}$ corrected to a vacuum basis and the molecular weight used was $116 \cdot 163$.

\section{Calorimetric apparatus}

Details of the automatic adiabatic calorimeter and its operation have been fully presented elsewhere ${ }^{3}, 4$. The sample container was of platinum, 
joined with gold solder and contained a soft-glass cap which was sealed off to close the container hermetically. The container had a volume of about $70 \mathrm{~cm}^{3}$ and contained a central platinum resistance thermometer with ten re-entrant heater wells about midway on equidistant radii. Twenty circular heat-distributing discs were bonded to the heaters but not to the resistance thermometer or side. For filling, the container was sealed to a glass vacuum line. After evacuation the sample was distilled in under its own vapour pressure, and the glass filling line sealed off after addition of a few cubic centimetres of helium gas. The quantity of glass used was weighed and corrected for.

The platinum resistance thermometer $\left(R_{0}=92 \Omega\right)$ was calibrated by comparison with another platinum resistance thermometer calibrated by the National Bureau of Standards, and thus reproduced the temperature scale described by Hoge and Brickwedde ${ }^{5}$ and by Stimson ${ }^{6}$. The value $273 \cdot 15^{\circ} \mathrm{K}$ was used for the ice point and $4 \cdot 1840$ abs. J has been used to define the calorie.

\section{Heat capacity measurements}

Comparison of heat capacity measurements on $n$-heptane ${ }^{4}$ with the standard values reported by Ginnings and Furukawa ${ }^{7}$ has shown that this automatic adiabatic calorimeter is accurate to within 0.25 per cent above $50^{\circ} \mathrm{K}$, while below this temperature the uncertainty increases to as much as $\mathrm{l}$ per cent at $25^{\circ} \mathrm{K}$. Additional comparisons of heat capacity values with other laboratories are in agreement with these findings.

Indane was cooled to about $12^{\circ} \mathrm{K}$ after which intermittent quantities of heat were added, finally raising the temperature to about $300^{\circ} \mathrm{K}$. A sharp peak was observed in the heat capacity at about $70^{\circ} \mathrm{K}$ and fusion at about $222^{\circ} \mathrm{K}$. After re-cooling to about $12^{\circ} \mathrm{K}$, intermittent heating raised the temperature to about $70^{\circ} \mathrm{K}$ where the transition was again passed. After re-cooling some degrees below the transition, heat inputs were resumed with smaller increments through the transition range. After re-cooling a second time to below the $70^{\circ} \mathrm{K}$ transition, intermittent heat inputs were made until the temperature of the sample reached about $320^{\circ} \mathrm{K}$. The fusion was carried out twice with continuous heating, after which the liquid range was measured to $310^{\circ} \mathrm{K}$. Temperature rises were about 10 per cent of the absolute temperature below $50^{\circ} \mathrm{K}$ and $5^{\circ}$ to $6^{\circ}$ above, and were small enough so that curvature corrections were unnecessary.

Indene was cooled to about $12^{\circ} \mathrm{K}$ and was heated to about $290^{\circ} \mathrm{K}$ with intermittent heat inputs. After re-cooling to about $12^{\circ} \mathrm{K}$ intermittent heat inputs were made until $320^{\circ} \mathrm{K}$ was reached while the fusion was carried out with continuous heating. After re-solidification, the fusion was again accomplished with continuous heating. Indene has an abrupt rise in its heat capacity at about $125^{\circ} \mathrm{K}$, similar to an annealing type of transition encountered with organic glasses, and in addition, a rather broad hump at about $210^{\circ}$ to $250^{\circ} \mathrm{K}$. Table 1 lists thermal data derived from the smoothed heat capacity data on indane and indene read from smoothed curves drawn through the experimental points. Few of the experimental points were more than 0.2 per cent from the "best curve". 
THERMODYNAMIC PROPERTIES OF INDANE AND INDENE

Table 1. Derived thermal data

\begin{tabular}{l|l|l|l|l}
\hline$T^{\circ}(\mathrm{K})$ & $C_{p}^{\circ}$ & $\begin{array}{c}S^{\circ} \\
\left(\mathrm{cal} \mathrm{mole}{ }^{-1} \mathrm{~K}-1\right)\end{array}$ & $\frac{H^{\circ}-H_{0}^{\circ}}{T}$ & $-\frac{F^{\circ}-H_{0}^{\circ}}{T}$ \\
\hline
\end{tabular}

Indane

\begin{tabular}{l|r|r|r|r}
\hline 15 & $1 \cdot 86$ & $0 \cdot 72$ & & \\
20 & $3 \cdot 24$ & $1 \cdot 45$ & $0 \cdot 53$ & $0 \cdot 19$ \\
25 & $4 \cdot 68$ & $2 \cdot 32$ & $1 \cdot 03$ & $0 \cdot 41$ \\
30 & $6 \cdot 03$ & $3 \cdot 30$ & $1 \cdot 62$ & $0 \cdot 71$ \\
40 & $8 \cdot 30$ & $5 \cdot 35$ & $3 \cdot 24$ & $1 \cdot 06$ \\
50 & $10 \cdot 28$ & $7 \cdot 42$ & $4 \cdot 48$ & $1 \cdot 87$ \\
60 & $12 \cdot 26$ & $9 \cdot 47$ & $5 \cdot 64$ & $2 \cdot 78$ \\
80 & $14 \cdot 43$ & $14 \cdot 04$ & $8 \cdot 15$ & $3 \cdot 72$ \\
100 & $16 \cdot 10$ & $17 \cdot 43$ & $9 \cdot 57$ & $5 \cdot 89$ \\
120 & $17 \cdot 84$ & $20 \cdot 52$ & $10 \cdot 80$ & $9 \cdot 86$ \\
& & & & $9 \cdot 72$ \\
140 & $19 \cdot 68$ & $23 \cdot 40$ & $11 \cdot 97$ & $11 \cdot 42$ \\
160 & $21 \cdot 66$ & $26 \cdot 16$ & $13 \cdot 06$ & $13 \cdot 10$ \\
180 & $23 \cdot 79$ & $28 \cdot 84$ & $14 \cdot 13$ & $14 \cdot 70$ \\
200 & $26 \cdot 04$ & $31 \cdot 46$ & $15 \cdot 21$ & $16 \cdot 25$ \\
220 & $28 \cdot 43$ & $34 \cdot 05$ & $16 \cdot 30$ & $17 \cdot 75$ \\
240 & $40 \cdot 70$ & $46 \cdot 71$ & $26 \cdot 76$ & $19 \cdot 95$ \\
260 & $42 \cdot 14$ & $50 \cdot 03$ & $27 \cdot 89$ & $22 \cdot 14$ \\
280 & $43 \cdot 80$ & $53 \cdot 21$ & $28 \cdot 96$ & $24 \cdot 24$ \\
$298 \cdot 15$ & $45 \cdot 47$ & $56 \cdot 01$ & $29 \cdot 92$ & $26 \cdot 09$ \\
300 & $45 \cdot 65$ & $56 \cdot 29$ & $30 \cdot 01$ & $26 \cdot 28$ \\
320 & $47 \cdot 79$ & $59 \cdot 31$ & $31 \cdot 06$ & $28 \cdot 25$ \\
& & & & \\
\hline
\end{tabular}

Indene

\begin{tabular}{|c|c|c|c|c|}
\hline $\begin{array}{l}15 \\
20 \\
25 \\
30 \\
40\end{array}$ & $\begin{array}{l}2 \cdot 13 \\
3 \cdot 42 \\
4 \cdot 66 \\
5 \cdot 77 \\
7 \cdot 64\end{array}$ & $\begin{array}{l}0.91 \\
1.71 \\
2 \cdot 60 \\
3.55 \\
5.48\end{array}$ & $\begin{array}{l}0.66 \\
1 \cdot 19 \\
1 \cdot 76 \\
2 \cdot 34 \\
3 \cdot 44\end{array}$ & $\begin{array}{l}0 \cdot 26 \\
0 \cdot 51 \\
0 \cdot 84 \\
1 \cdot 21 \\
2 \cdot 04\end{array}$ \\
\hline $\begin{array}{r}50 \\
60 \\
80 \\
100 \\
120\end{array}$ & $\begin{array}{r}9 \cdot 09 \\
10 \cdot 35 \\
12 \cdot 48 \\
14 \cdot 22 \\
16 \cdot 02\end{array}$ & $\begin{array}{r}7 \cdot 35 \\
9 \cdot 12 \\
12 \cdot 40 \\
15 \cdot 38 \\
18 \cdot 12\end{array}$ & $\begin{array}{l}4 \cdot 43 \\
5 \cdot 32 \\
6 \cdot 72 \\
8 \cdot 05 \\
9 \cdot 22\end{array}$ & $\begin{array}{l}2 \cdot 92 \\
3 \cdot 80 \\
5 \cdot 67 \\
7 \cdot 32 \\
8 \cdot 89\end{array}$ \\
\hline $\begin{array}{l}140 \\
160 \\
180 \\
200 \\
220\end{array}$ & $\begin{array}{l}19 \cdot 35 \\
21 \cdot 54 \\
23 \cdot 64 \\
25 \cdot 81 \\
28 \cdot 56\end{array}$ & $\begin{array}{l}20 \cdot 86 \\
23 \cdot 56 \\
26 \cdot 22 \\
28 \cdot 82 \\
31 \cdot 40\end{array}$ & $\begin{array}{l}10 \cdot 45 \\
11 \cdot 70 \\
12.91 \\
14 \cdot 09 \\
15 \cdot 28\end{array}$ & $\begin{array}{l}10 \cdot 41 \\
11 \cdot 85 \\
13 \cdot 30 \\
14 \cdot 09 \\
16 \cdot 12\end{array}$ \\
\hline $\begin{array}{l}240 \\
260 \\
280 \\
298 \cdot 15 \\
300 \\
320\end{array}$ & $\begin{array}{l}31 \cdot 42 \\
34 \cdot 02 \\
43 \cdot 25 \\
44 \cdot 68 \\
44 \cdot 84 \\
46 \cdot 54\end{array}$ & $\begin{array}{l}34 \cdot 01 \\
36 \cdot 62 \\
48 \cdot 43 \\
51 \cdot 19 \\
51 \cdot 47 \\
54 \cdot 21\end{array}$ & $\begin{array}{l}16 \cdot 50 \\
17 \cdot 74 \\
27.92 \\
28 \cdot 89 \\
28.99 \\
30 \cdot 06\end{array}$ & $\begin{array}{l}17 \cdot 51 \\
18 \cdot 88 \\
20 \cdot 51 \\
22 \cdot 30 \\
22 \cdot 48 \\
24 \cdot 14\end{array}$ \\
\hline
\end{tabular}




\section{Transition data}

\section{RESULTS}

The heat capacity of indane begins to rise sharply at about $68^{\circ} \mathrm{K}$ and reaches a measured value of $138.88 \mathrm{cal} \mathrm{mole}^{-1}{ }^{\circ} \mathrm{K}-1$ at $73.82^{\circ} \mathrm{K}$ : the value at $74.28^{\circ} \mathrm{K}$ has receded to $33.21 \mathrm{cal} \mathrm{mole}^{-1}{ }^{\circ} \mathrm{K}^{-1}$. By $78^{\circ} \mathrm{K}$ the heat capacity curve is rising smoothly again. Two separate runs through the transition region gave for the total heat absorbed between $68^{\circ}$ and $78^{\circ} \mathrm{K}$ the values 187.0 and $186.1 \mathrm{cal} / \mathrm{mole}$, indicating that the transition is reasonably reversible and free from hysteresis. Pre-melting seems to begin about $170^{\circ} \mathrm{K}$ and $180^{\circ} \mathrm{K}$ and becomes more pronounced as the melting point is approached. The heat of melting in the pre-melting region is about 0.3 to 0.5 per cent. The heats of melting for the four runs were $2054 \cdot 8,2056 \cdot 0$, $2054 \cdot 8$ and $2055 \cdot 0$, making the average value $2055 \pm 2 \mathrm{cal} / \mathrm{mole}$. Purity of the sample was calculated from melting data taken during intermittent melting, and tabulated in Table 2 where $F$ is the weight fraction melted. Our sample melted at $221.715^{\circ} \mathrm{K}$, extrapolated to a pure melting point of $221 \cdot 77^{\circ} \mathrm{K}$, and gave a calculated purity of $99 \cdot 89$ mole per cent. The sample appears to behave ideally.

The shape of the solid heat capacity curve of indene does not give much of a clue regarding the presence or absence of pre-melting. The heats of melting for three runs were $2440 \cdot 3,2435 \cdot 9$, and $2437 \cdot 7$, making the average value $2438 \pm 3 \mathrm{cal} /$ mole. Purity calculated on the basis of the pre-melting heat capacity indicates about 99.95 mole per cent. Purity calculated from fractional melting data is tabulated in Table 3 and indicates a purity of about 99.91 mole per cent although a plot of temperature versus the reciprocal of the fraction melted does not give a straight line, indicating that the

Table 2. Equilibrium fraction of indane melted $(F)$ vs. temperature

\begin{tabular}{c|c|c}
\hline$T^{\circ}(\mathrm{K})$ & $F$ & $1 / F$ \\
\hline 221.438 & $0 \cdot 129$ & $7 \cdot 74$ \\
221.570 & 0.238 & $4 \cdot 20$ \\
221.616 & 0.351 & $2 \cdot 85$ \\
221.651 & 0.463 & $2 \cdot 16$ \\
221.673 & 0.575 & 1.74 \\
221.687 & 0.690 & 1.45 \\
221.703 & 0.800 & 1.25 \\
221.714 & 0.909 & $1 \cdot 10$ \\
\hline
\end{tabular}

Table 3. Equilibrium fraction of indene melted $(F)$ vs. temperature

\begin{tabular}{c|c|c}
\hline$T^{\circ}(\mathrm{K})$ & $F$ & $1 / F$ \\
\hline 271.508 & 0.294 & 3.40 \\
271.541 & 0.413 & 2.42 \\
271.565 & 0.532 & 1.88 \\
271.582 & 0.654 & 1.53 \\
271.598 & 0.775 & 1.29 \\
271.614 & 0.893 & 1.12 \\
\hline
\end{tabular}




\section{THERMODYNAMIC PROPERTIES OF INDANE AND INDENE}

system departs rather widely from ideality. If the impurity forms a solid solution, application of the calculational method of Mastrangelo and Dornte $^{8}$ leads to a purity of 99.68 mole per cent. No one of these treatments is in agreement with all the facts, so the purity must be regarded as not established. The melting point of pure indene was taken as $271 \cdot 70^{\circ} \mathrm{K}$.

\section{Entropy}

Both heat capacity curves were extrapolated from about $15^{\circ} \mathrm{K}$ to $0^{\circ} \mathrm{K}$ by a combination of Einstein and Debye functions. For indane three degrees of Debye freedom with $\theta=86^{\circ}$ and three degrees of Einstein freedom with $\theta=121^{\circ}$ were used, while for indene three degrees of Debye freedom with $\theta=77.5^{\circ}$ and three degrees of Einstein freedom with $\theta=136^{\circ}$. From $15^{\circ} \mathrm{K}$ to $198 \cdot 15^{\circ} \mathrm{K}$ the heat capacity was graphically integrated. These entropy calculations are summarized in Tables 4 and 5 .

Table 4. Calorimetric entropy of indane

\begin{tabular}{l|c}
\hline & $S^{\circ}\left(\mathrm{cal} \mathrm{mole}^{-1{ }^{\circ} \mathrm{K}-1}\right)$ \\
\hline $0^{\circ} \mathrm{K}-15^{\circ} \mathrm{K}\left[C_{v}=3^{\circ} \mathrm{D}\left(\frac{86}{T}\right)+3^{\circ} \mathrm{E}\left(\frac{121}{T}\right)\right]$ & $0 \cdot 724$ \\
$15^{\circ} \mathrm{K}-221 \cdot 77^{\circ} \mathrm{K}$ (graphical) & $33 \cdot 555$ \\
$\mathrm{Melting}, 2055 / 221^{\circ} \cdot 77$ & $9 \cdot 266$ \\
$221 \cdot 77^{\circ} \mathrm{K}-298 \cdot 15^{\circ} \mathrm{K}$ (graphical) & $\frac{12 \cdot 464}{56 \cdot 01 \pm 0 \cdot 10}$ \\
Entropy of liquid indane at $298 \cdot 15^{\circ} \mathrm{K}$ & \\
\hline
\end{tabular}

Table 5. Calorimetric entropy of indene

\begin{tabular}{l|c}
\hline & $S^{\circ}\left(\right.$ cal mole $\left.{ }^{-1} \mathrm{~K}^{-1}\right)$ \\
\hline $0^{\circ} \mathrm{K}-15^{\circ} \mathrm{K}\left[C_{v}=3^{\circ} \mathrm{D}\left(\frac{77 \cdot 5}{T}\right)+3^{\circ} \mathrm{E}\left(\frac{136}{T}\right)\right]$ & 0.912 \\
$15^{\circ} \mathrm{K}-271 \cdot 70^{\circ} \mathrm{K}$ (graphical) & $37 \cdot 251$ \\
Melting, $2438 / 271 \cdot 70$ & $8 \cdot 973$ \\
$271 \cdot 70^{\circ} \mathrm{K}-298 \cdot 15^{\circ} \mathrm{K}$ (graphical) & $\frac{4 \cdot 053}{51 \cdot 19 \pm 0 \cdot 10}$ \\
Entropy of liquid indene at $298 \cdot 15^{\circ} \mathrm{K}$ & \\
\hline
\end{tabular}

\section{Vapour pressure}

Vapour pressures were measured in a twin ebulliometer system in which the compounds and water boiled simultaneously at a common pressure. Equilibrium boiling temperatures were observed simultaneously for water and indane and for water and indene. The pressure in the system was calculated from the boiling temperature of the water, since the vapour pressure of water is well established. The experimental points were fitted by a least-squares method to the Antoine equation. The Antoine equation for indane: $\log P_{\mathrm{mm}}=7 \cdot 05483-1625 \cdot 70 /(t+211 \cdot 645)$, and for indene: $\log P_{\mathrm{mm}}=6.87071-1507 \cdot 80 /(t 195 \cdot 313),\left(t+\right.$ in $\left.{ }^{\circ} \mathrm{C}\right)$, were used to calculate the vapour pressure values presented in Table 6 . 
D. STULL, G. SINKE, R. McDONALD, W. HATTON AND D. HILDENBRAND

Table 6. Vapour pressures of indane and indene

\begin{tabular}{|c|c|c|c|}
\hline \multicolumn{4}{|c|}{ Indane pressures $(\mathrm{mm})$} \\
\hline$t\left({ }^{\circ} \mathrm{C}\right)$ & Obs. & Calc. & (Calc.-Obs.) \\
\hline $\begin{array}{l}179 \cdot 09 \\
178 \cdot 04 \\
176 \cdot 03\end{array}$ & $\begin{array}{l}783 \cdot 38 \\
763 \cdot 03 \\
727 \cdot 55\end{array}$ & $\begin{array}{l}783 \cdot 72 \\
763 \cdot 75 \\
726 \cdot 62\end{array}$ & $\begin{array}{l}+0.34 \\
+0.72 \\
-0.93\end{array}$ \\
\hline $\begin{array}{r}152 \cdot 36 \\
128 \cdot 56 \\
107 \cdot 38 \\
91 \cdot 68\end{array}$ & $\begin{array}{r}388 \cdot 28 \\
189 \cdot 10 \\
90 \cdot 65 \\
49 \cdot 68\end{array}$ & $\begin{array}{r}387 \cdot 82 \\
188 \cdot 88 \\
90 \cdot 97 \\
49 \cdot 56\end{array}$ & $\begin{array}{l}-0.46 \\
-0.22 \\
+0.32 \\
-0.12\end{array}$ \\
\hline \multicolumn{4}{|c|}{ Indene pressures $(\mathrm{mm})$} \\
\hline $\begin{array}{l}183 \cdot 82 \\
182 \cdot 72 \\
180 \cdot 79\end{array}$ & $\begin{array}{l}783 \cdot 11 \\
763 \cdot 03 \\
727 \cdot 81\end{array}$ & $\begin{array}{l}782 \cdot 90 \\
762 \cdot 32 \\
727 \cdot 23\end{array}$ & $\begin{array}{l}-0.21 \\
-0.71 \\
-0.58\end{array}$ \\
\hline $\begin{array}{r}156.95 \\
132 \cdot 89 \\
111.48 \\
96.06\end{array}$ & $\begin{array}{r}387 \cdot 81 \\
189 \cdot 36 \\
90 \cdot 60 \\
49 \cdot 60\end{array}$ & $\begin{array}{r}389 \cdot 36 \\
189 \cdot 04 \\
90 \cdot 35 \\
49 \cdot 68\end{array}$ & $\begin{array}{r}+1.55 \\
-0.32 \\
-0.25 \\
+0.08\end{array}$ \\
\hline
\end{tabular}

\section{Heats of combustion}

Heats of combustion of the low-temperature samples were determined by standard bomb calorimetry ${ }^{9}$. The combustion calorimeter was calibrated with N.B.S. benzoic acid. Samples were enclosed in "Mylar" film to prevent evaporation and exposure to oxygen. All weights were corrected to true mass (weight in vacuum). Corrections to standard states of pure liquids and gases at one atmosphere were calculated by the method of Prosen ${ }^{10}$. Results are for $298 \cdot 15^{\circ} \mathrm{K}$ and a constant pressure of one atmosphere. The heat of combustion refers to the reaction with oxygen to form liquid water $\left(\Delta H_{\mathrm{f}, 298^{\circ} \mathrm{K}}^{\circ}=-68.317 \mathrm{kcal} / \mathrm{mole}\right)$, and gaseous carbon dioxide $\left(\Delta H_{\mathrm{f}, 298^{\circ} \mathrm{K}}^{\circ}=-94.054 \mathrm{kcal} / \mathrm{mole}\right)$. The heat of formation refers to the reaction of graphite and hydrogen to form liquid indane or indene. Atomic weights used were $\mathrm{C}=12.011$ and $\mathrm{H}=1.0080$. The values given in Table 7 are the averages of five combustions on each material.

Uncertainties are equal to twice the overall standard deviation.

Table 7. Heat of combustion and formation of indane and indene at $298 \cdot 15^{\circ} \mathrm{K}$

\begin{tabular}{l|c|c}
\hline & $\begin{array}{c}\Delta H_{\mathrm{c}} \\
(\mathrm{kcal} / \mathrm{mole})\end{array}$ & $\begin{array}{c}\Delta H_{\mathrm{f}} \\
(\mathrm{kcal} / \mathrm{mole})\end{array}$ \\
\hline $\begin{array}{l}\text { Indane (liquid) } \\
\text { Indene (liquid) }\end{array}$ & $-1190 \cdot 63 \pm 0.47$ & $\begin{array}{r}+2 \cdot 56 \pm 0.47 \\
+26.39 \pm 0.30\end{array}$ \\
\hline
\end{tabular}

The difference between the values in the third column of Table 7 represents the heat of hydrogenation of liquid indene to form liquid indane, which is $-23,830 \pm 770 \mathrm{cal} / \mathrm{mole}$. Dolliver, Gresham, Kistiakowsky; and 


\section{THERMODYNAMIC PROPERTIES OF INDANE AND INDENE}

Vaughan ${ }^{1}$ measured the heat of hydrogenation of indene to indane in the gas phase at $373^{\circ} \mathrm{K}$, and reported $-24,200 \pm 500 \mathrm{cal} / \mathrm{mole}$. Since the heats of vaporization for indane and indene are expected to be similar, these heats of hydrogenation are in agreement within experimental error.

\section{Thermodynamic properties at $298 \cdot 15^{\circ} \mathrm{K}$}

The entropy and heat of formation data given above may be combined with the entropies of the elements ${ }^{11}$ to calculate free energies of formation of indane and indene. Thermodynamic properties of $o$-ethyltoluene were taken from the compilation of the American Petroleum Institute Research Project $44^{12}$. These thermodynamic properties are summarized in Table 8 .

Table 8. Thermodynamic properties at $298 \cdot 15^{\circ} \mathrm{K}$

\begin{tabular}{l|c|c|c}
\hline & $\Delta F_{\mathrm{f}}^{\mathrm{o}}(\mathrm{kcal} / \mathrm{mole})$ & $\Delta H_{\mathrm{i}}^{\circ}(\mathrm{kcal} / \mathrm{mole})$ & $S^{\circ}\left(\mathrm{cal} \mathrm{mole}{ }^{-10} \mathrm{~K}^{-1}\right)$ \\
\hline o-Ethyltoluene (liq.) & 27.97 & $-11 \cdot 11$ & $68 \cdot 42$ \\
Indane (liq.) & 36.06 & $2 \cdot 56$ & $56 \cdot 01$ \\
Indene (liq.) & $52 \cdot 02$ & $26 \cdot 39$ & $51 \cdot 19$ \\
Hydrogen (gas) & 0 & 0 & $31 \cdot 21$ \\
\hline
\end{tabular}

On the basis of these data, the extent of two reactions at thermodynamic equilibrium has been calculated.

$$
o \text {-Ethyltoluene } \rightleftharpoons \text { Indane }+ \text { Hydrogen }
$$

Reaction (i) indicates the cracking of liquid o-ethyltoluene at $25^{\circ} \mathrm{C}$ to form liquid indane and hydrogen gas:

$$
\begin{aligned}
& \Delta F_{\mathrm{R}, 25^{\circ} \mathrm{C}}=36.06-27.97=+8.09 \mathrm{kcal} \\
& \Delta H_{\mathrm{R}, 25^{\circ} \mathrm{C}}=2.56-(-11 \cdot 11)=+13.67 \mathrm{kcal} \\
& \Delta S_{\mathrm{R}, 25^{\circ} \mathrm{C}}=56.01+31.21-68.42=18.80 \mathrm{cal} /{ }^{\circ} \mathrm{K}
\end{aligned}
$$

The free energy change indicates that no indane would be formed at room temperature, but the large positive entropy change indicates that indane formation would be favoured at higher temperatures. Assuming that the heat and entropy changes in the reaction remain reasonably constant with temperature and that the heats of vaporization at $25^{\circ} \mathrm{C}$ are comparable, calculation shows that the free energy change for the reaction, $\Delta F_{R}$, should be equal to zero at about $750^{\circ} \mathrm{K}\left(480^{\circ} \mathrm{C}\right)$. This means that roughly equal amounts of 0 -ethyltoluene and indane would be present at that temperature, and that above $750^{\circ} \mathrm{K}$ the formation of indane becomes increasingly favoured. Experience has shown that the assumptions regarding the constancy of $\Delta H$ and $\Delta S$ are reasonable.

For the reaction of dehydrogenating liquid indane to indene liquid and gaseous hydrogen:

$$
\text { Indane } \rightleftharpoons \text { Indene }+ \text { Hydrogen }
$$

$$
\begin{aligned}
& \Delta F_{\mathrm{R}, 25^{\circ} \mathrm{C}}=52.02-36.06=+15.96 \mathrm{kcal} \\
& \Delta H_{\mathrm{R}, 25^{\circ} \mathrm{C}}=26.39-2.56=+23.83 \mathrm{kcal} \\
& \Delta S_{\mathrm{R}, 25^{\circ} \mathrm{C}}=51 \cdot 19+31.21-56.01=+26.39 \mathrm{cal} /{ }^{\circ} \mathrm{K}
\end{aligned}
$$


D. STULL, G. SINKE, R. McDONALD, W. HATTON AND D. HILDENBRAND

Here, also, the free energy change indicates that the dehydrogenation of indane to indene does not occur to any measurable extent at room temperature. Again, however, the large positive entropy change indicates that indene formation should be favoured at higher temperatures. Making the same assumptions regarding the constancy of $\Delta H$ and $\Delta S$ and again assuming the heats of vaporization to be comparable, the free energy change in reaction (ii) should be zero at about $900^{\circ} \mathrm{K}\left(630^{\circ} \mathrm{C}\right)$. In the temperature range $600^{\circ} \mathrm{C}$ to $750^{\circ} \mathrm{C}$, these results indicate that roughly equal amounts of indane and indene may be present around $600^{\circ} \mathrm{C}$, but at $750^{\circ} \mathrm{C}$ indene should be favoured over indane by a ratio of almost ten to one.

Naidus and Mueller ${ }^{2}$ have presented an experimental study of the indene-indane-hydrogen system from $375^{\circ} \mathrm{C}$ to $525^{\circ} \mathrm{C}$. Their results are in reasonably good agreement with these thermodynamic calculations, but indicate that $\Delta F$ for reaction (ii) should be equal to zero at about $530^{\circ} \mathrm{C}$, about $100^{\circ}$ lower than our calculated value. Considering the errors involved, we are inclined to average the two sets of results and conclude that indane and indene will be present in roughly equal amounts at about $580^{\circ} \mathrm{C}$. Above this temperature, of course, indene predominates.

\section{References}

${ }^{1}$ M. A. Dolliver, T. L. Gresham, G. B. Kistiakowsky and W. E. Vaughan. F. Am. Chem. Soc., 59, 831 (1937)

2 E. S. Naidus and M. B. Mueller. F. Am. Chem. Soc., 72, 1829 (1950)

${ }^{3}$ D. R. Stull. Anal. Chim. Acta., 17, 133 (1957)

D. L. Hildenbrand, W. R. Kramer, R. A. McDonald and D. R. Stull. 7. Am. Chem. Soc., 80, 4129 (1958)

5 H. Hoge and F. G. Brickwedde. F. Research Nat. Bur. Standards, 22, 351 (1939)

- H. F. Stimson. F. Research Nat. Bur. Standards, 42, 209 (1949)

${ }^{7}$ D. C. Ginnings and G. T. Furukawa. 7. Am. Chem. Soc., 75, 522 (1953)

${ }^{8}$ S. V. R. Mastrangelo and R. W. Dornte. J. Am. Chem. Soc., 77, 6200 (1955)

- G. C. Sinke, D. L. Hildenbrand, R. A. McDonald, W. R. Kramer and D. R. Stull. 7. Phys. Chem., 62, 1461 (1958)

10 E. J. Prosen. 7. Research Nat. Bur. Standards Report No. 1119, Aug. 6 (1951)

11 D. R. Stull and G. C. Sinke. Thermodynamic Properties of the Elements, No. 18 of the Advances in Chemistry Series Edited by the Staff of Industrial and Engineering Chemistry, American Chemical Society, Washington 6, D.C.

12 F. D. Rossini, K. S. Pitzer, R. M. Arnett, R. M. Braun and G. C. Pimentel. Selected Values of Physical and Thermodynamic Properties of Hydrocarbons and Related Compounds, Carnegie Press, Pittsburgh, Penna. (1953) 